Original Research

\title{
Production of Fermentable Sugars from Cassava Stem using Hybrid Pretreatment Technology
}

Selvaraju Sivamani ${ }^{1,{ }^{*}}$, Rajoo Baskar ${ }^{2}$, Balasubramanian Lakshmi ${ }^{3}$

1. Chemical Engineering Section, Engineering Department, University of Technology and Applied Sciences (Salalah College of Technology), Salalah, Oman; E-Mail: sivmansel@gmail.com

2. Department of Food Technology, School of Chemical and Food Sciences, Kongu Engineering College, Perundurai, Erode, India; E-Mail: erbaskar@kongu.ac.in

3. Department of Biotechnology, Kumaraguru College of Technology, Coimbatore, India; E-Mail: lakshmi.skal@gmail.com

* Correspondence: Selvaraju Sivamani; E-Mail: sivmansel@gmail.com

Academic Editor: Alberto Romero, Victor Perez-Puyana and Mercedes Jiménez-Rosado

Special Issue: Characterization, Recovery and Valorization of Protein Concentrates from Residues and By-products of Agri-food Industry

Recent Progress in Materials

2021, volume 3, issue 3

doi:10.21926/rpm.2103037
Received: April 29, 2021

Accepted: September 06, 2021

Published: September 14, 2021

\begin{abstract}
One of the crucial steps in the enzymatic hydrolysis of biomass is pretreatment. We investigated the applicability of a hybrid pretreatment method, This involved acid treatment followed by alkali before the production of fermentable sugars from cassava stem. The substrate was initially treated with acid ( $1 \%$ oxalic acid at $100{ }^{\circ} \mathrm{C}$ for $2 \mathrm{~h}$ ), followed by treatment with a $10 \% \mathrm{NaOH}$-urea mixture (by mixing $5 \mathrm{~g}$ each of $\mathrm{NaOH}$ and urea in $100 \mathrm{~mL}$ of water) at $100{ }^{\circ} \mathrm{C}$ for $1 \mathrm{~h}$. A cellulose recovery of $98.55 \%$ was obtained with the acid-alkali pretreatment method.
\end{abstract}

\section{Keywords}

Cassava stem; acid pretreatment; alkali delignification; fermentable sugars

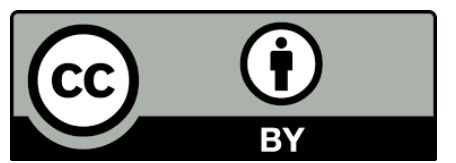

(C) 2021 by the author. This is an open access article distributed under the conditions of the Creative Commons by Attribution License, which permits unrestricted use, distribution, and reproduction in any medium or format, provided the original work is correctly cited. 


\section{Introduction}

Fermentable sugars are renewable resources that are used to produce bioethanol, an interesting alternative to the current fossil fuels [1]. A suitable feedstock is required for the production of fermentable sugars and the sustainable development of society [2]. The selection of feedstock is affected by factors such as its availability, technological level, and its environmental and ecological effects [3]. Two historical changes have occurred due to practical conditions and economic considerations. The first change occurred around 200 years ago when coal became the primary feedstock in place of renewable biomass. The second change occurred around 50 years ago when crude oil was replaced by coal. These changes have tremendously affected the industries in the past 200 years [4]. The current industrial development is based on a cheap and steady feedstock supply [5]. The primary challenges for the production of fermentable sugars are low yield and the high cost of the hydrolysis process [6].

Pretreatment is necessary to remove lignin and hemicellulose, reduce the crystallinity of cellulose, and increase the porosity of lignocellulosic materials [7]. An effective pretreatment process should meet the following requirements: (a) it should preserve and decrystallize cellulose, and depolymerize hemicellulose; (b) it should restrict the formation of inhibitors that resist the hydrolysis of carbohydrates; (c) it should have a low energy input and result in the recovery of valueadded products such as lignin, and (d) it should be cost-effective [8]. The complex carbohydrates such as cellulose and hemicellulose are subsequently hydrolyzed to form fermentable sugars, which are then converted to ethanol by microbial action. Based on the pretreatment conditions, the type of biomass and the properties of hydrolytic agents, acid, and enzymatic approaches are used for biomass hydrolysis [9].

Lignocellulosic materials are being used to overcome the challenges [10]. They are the major structural components of all plants and are produced by different industries such as pulp, forestry, agricultural, and food [11]. They contain three main components, namely cellulose, hemicellulose, and lignin, along with smaller amounts of ash, extractives, pectin, and proteins [12]. Lignin prevents the destruction of plant cells from fungal or bacterial infection, required for the conversion to fuel, whereas strong alkali are used for delignification [13]. Cellulose is the repeat unit of D-glucose and is found in its organized fibrous structure. D-glucose units are linked together by $\beta$ - $(1,4)$-glycosidic bonds [14]. Hemicellulose consists of different sugars such as pentoses (xylose, rhamnose, and arabinose), uronic acid, and hexoses (glucose, mannose, and galactose), with xylose comprising about $90 \%$ of the total content. Dilute acid hydrolysis is a common method of pretreatment that allows the hydrolysis of sugars [15]. First, hemicellulose and cellulose are broken down into their monomers. Next, the lignocellulosic material is pretreated to remove the disrupted structure of lignin and expose cellulose to enzymatic hydrolysis [16].

The pretreatment methods used for simultaneous hemicellulose dissolution and delignification are concentrated acid hydrolysis, dilute acid hydrolysis, strong alkali pretreatment, sodium chlorite treatment, and organic solvent treatment [17]. During dilute acid hydrolysis, lignocellulosic biomass removes the hemicellulose and certain fractions of lignin, and the remaining lignin is intact with the cellulosic substrate. During strong alkali pretreatment, delignification occurs [18]. Different acids 
used for pretreatment are sulfuric acid and oxalic acid. Dilute acid hydrolysis is performed at high temperatures in the presence of a low concentration of the acid. Dilute acid is an effective pretreatment method due to its low cost and easy availability [19]. A strong alkali solution split the connecting bonds in lignin and glycosidic linkages of polysaccharides, thereby decreasing the degree of polymerization and crystallinity, fiber swelling, as well as comminution of the structure of lignin [20].

Although hybrid technology is not novel in the pretreatment of lignocellulosic materials and leads to costlier operations in the production of fermentable sugars, it has the dual advantages of hemicellulose dissolution and simultaneous delignification [21, 22]. Based on the literature, the following objectives were framed: (i) To characterize the cassava stem for its biochemical composition and (ii) to study the pretreatment conditions with acid-alkali and chemical saccharification for a high yield of fermentable sugars from cassava stem.

\section{Materials and Methods}

\subsection{Materials}

Cassava stem was kindly provided by a farmer in the Namakkal district of Tamil Nadu state, India. Maleic acid, malic acid, adipic acid, tartaric acid, pyruvic acid, oxalic acid, citric acid, hydrochloric acid, sulfuric acid, phosphoric acid, nitric acid, formic acid, acetic acid, perchloric acid, sodium hydroxide, potassium hydroxide, and urea of analar grade from purchased from Finar Chemicals Limited, Ahmedabad. The water bath was bought from Narang Scientific Works and a hot air oven from Kadavil Electro-Mechanical Industries. An Elico SL 150 UV-visible spectrophotometer was used.

\subsection{Methods}

\subsubsection{Biochemical Characterization of Cassava Stem}

Cellulose content was determined as follows [23]:

To $1 \mathrm{~g}$ of cassava stem, $3 \mathrm{~mL}$ of acetic-nitric acid solution was added, followed by incubation at $100^{\circ} \mathrm{C}$ for $30 \mathrm{~min}$. This solution was filtered using a Buchner funnel and then washed using hot water to enhance the filtration. The residue was collected in a Petri dish; it was dried under a hot air oven. The dried sample was measured, and the cellulose content was calculated using the formula:

$$
\text { Cellulose content }(\%)=\frac{\text { Mass of cellulose }}{\text { Mass of dried cassava stem }} \times 100
$$

The lignin content was estimated using a previously described method [24]:

To $1 \mathrm{~g}$ of cassava stem, $5 \mathrm{~mL}$ of $72 \%(\mathrm{v} / \mathrm{v})$ sulfuric acid solution was added. This solution was kept on a shaker for $1 \mathrm{~h}$ at $130 \mathrm{rpm}$. To this, $120 \mathrm{~mL}$ of distilled water was added, and the solution was autoclaved for $1 \mathrm{~h}$. The solution was filtered using a Buchner funnel and washed using hot water to enhance the filtration. The residue was collected in a Petri dish and dried under a hot air oven. The dried sample was measured, and the lignin content was calculated using the formula

$$
\text { Lignin content }(\%)=\frac{\text { Mass of lignin }}{\text { Mass of dried cassava stem }} \times 100
$$


The hemicellulose content was calculated as follows [25]:

To $1 \mathrm{~g}$ of cassava stem taken in a conical flask, $20 \mathrm{~mL}$ of sulfuric acid $(3 \%(\mathrm{v} / \mathrm{v})$ was added. The conical flask was autoclaved for $1 \mathrm{~h}$ and cooled, following which 60 to $70 \mathrm{~mL}$ of distilled water was added, and the $\mathrm{pH}$ was adjusted to 7.0-7.5. Finally, the volume was made to $1 \mathrm{~L}$. The xylose concentration was measured using the dinitrosalicylic acid method, assuming that $90 \%$ of hemicellulose was xylan and 0.9 was the theoretical product yield coefficient of monosaccharides.

$$
\text { Hemicellulose content }(\%)=\frac{\text { Mass of xylose } \times 0.9 \times 0.9}{\text { Mass of dried cassava stem }} \times 100
$$

The ash content was measured as follows [26]:

The cassava stem was weighed and placed in a muffle furnace at $550{ }^{\circ} \mathrm{C}$ for $3 \mathrm{~h}$. Next, the material was weighed, and the ash content was calculated using the formula

$$
\text { Ash content }(\%)=\frac{\text { Mass of ash }}{\text { Mass of dried cassava stem }} \times 100
$$

Extractive content was evaluated as follows:

$$
\text { Extractives }(\%)=100-(\text { Cellulose } \%-\text { Lignin \% }- \text { Hemicellulose } \%-\text { Ash \% })
$$

\subsubsection{Acid Pretreatment}

The cassava stem $(7.5 \mathrm{~g} / \mathrm{L}$ of the feed solution) was added with an acid solution at a solid to liquid ratio. Next, it was kept at $100{ }^{\circ} \mathrm{C}$ for a specific residence time. The solid fraction obtained was filtered through a filter paper, and the supernatant was used to estimate the xylose content using the dinitrosalicylic acid method. The optical density was measured at $540 \mathrm{~nm}$. The remaining solid residues were oven-dried at $80^{\circ} \mathrm{C}$ to constant weight and further proceeded for hydrolysis.

\subsubsection{Alkali Delignification}

The cassava stem was mixed with an alkali solution at a particular solid to liquid ratio. Thereafter, the mixture was shaken vigorously to blend it well. In the case of mixed alkali solution, alkalis were added in equal proportions. Next, it was kept in a boiling water bath $\left(100^{\circ} \mathrm{C}\right)$ for a specific residence time. The solid fraction obtained was filtered through filter paper. The solid residue was rinsed with distilled water to a $\mathrm{pH}$ of 7.0 . The remaining solid residues were oven-dried at $80^{\circ} \mathrm{C}$ to constant weight and further proceeded for hydrolysis.

\subsubsection{Fermentable Sugars by Dinitrosalicylic Acid Method}

The DNSA reagent was prepared by adding $1 \mathrm{~g}$ of 3,5-dinitrosalicylic acid, $1 \mathrm{~g}$ of $\mathrm{NaOH}, 200 \mathrm{mg}$ of crystalline phenol, $50 \mathrm{mg}$ of sodium sulfite, and $40 \mathrm{~g}$ of potassium sodium tartrate to $100 \mathrm{~mL}$ of water. All chemicals were mixed well using a magnetic stirrer for complete dissolution. The stock solution was prepared by adding $10 \mathrm{mg}$ of xylose in $100 \mathrm{~mL}$ of water. Cleaned and dried test tubes were taken, and the standard solutions were prepared by taking $0,1,2,3,4$, and $5 \mathrm{~mL}$ of the stock solution in each tube and made up to $5 \mathrm{~mL}$ with distilled water. Next, $5 \mathrm{~mL}$ of solution from the test sample was added to the 7 th test tube. Afterward, $3 \mathrm{~mL}$ of the DNSA reagent was added to each of 
the seven test tubes. The contents were gently stirred to ensure mixing, and all the test tubes were placed in a boiling water bath (between 90 and $100{ }^{\circ} \mathrm{C}$ ) for $5 \mathrm{~min}$. The absorbance was recorded at $510 \mathrm{~nm}$, and the xylose concentration was calculated as follows:

$$
\text { Xylose content }(\%)=\left\{[C \times(V / a)] /\left[W \times 10^{6}\right]\right\} \times 100,
$$

where $C$ is the xylose content by referring to the standard curve $(\mu \mathrm{g}), \mathrm{V}$ is the total volume of the extracted solution $(\mathrm{mL})$, a is the volume of sample solution for color development $(\mathrm{mL})$, and $\mathrm{W}$ is the weight of the sample (g).

\subsubsection{Cellulose Recovery}

After acid-alkali pretreatment, the sample was dried at $105^{\circ} \mathrm{C}$ to a constant weight. Next, the mass of the sample was noted down $\left(\mathrm{W}_{1}\right)$, and cellulose recovery was calculated as follows:

$\%$ cellulose recovery

$$
=\frac{\text { Mass of cellulose }\left(W_{1}\right)}{\text { Mass of cassava stem } \times \text { Percentage of cellulose in cassava stem }} \times 100
$$

\section{Results and Discussion}

\subsection{Characterization of Cassava Stem}

The average biochemical composition of cassava stem is summarized in Figure 1. The hemicellulose content of the cassava stem was higher compared to that of cellulose. The result indicated that cassava stem could be a potential source for ethanol bioconversion.

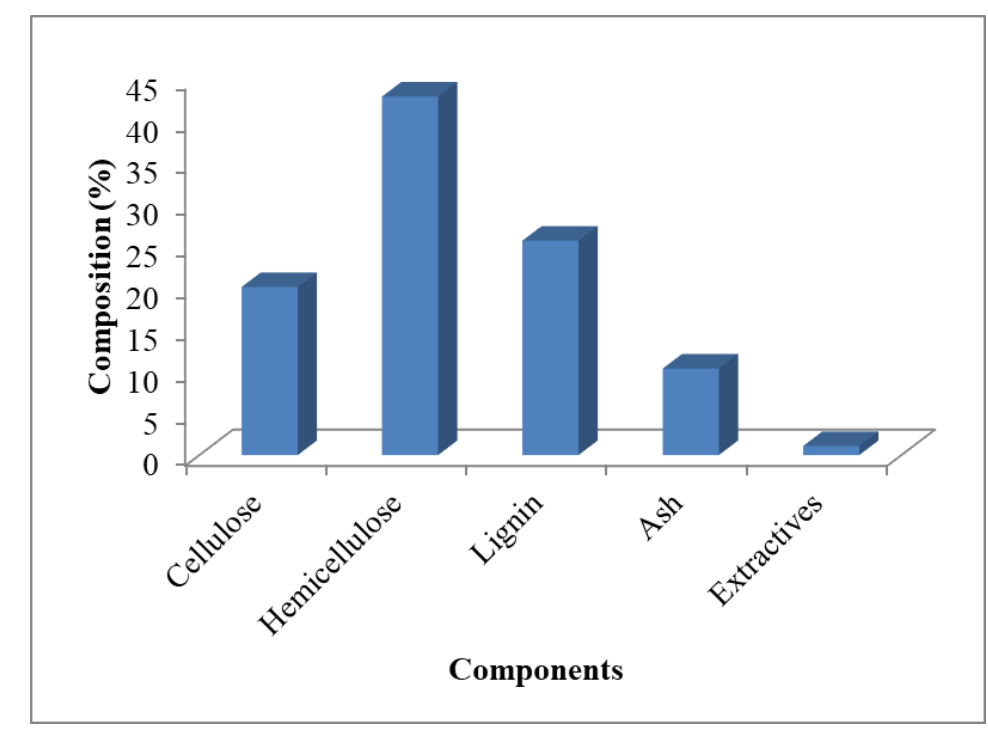

Figure 1 Biochemical characterization of cassava stem.

Figure 2 reveals the effect of solid organic acids on xylose concentration for coarse particles of cassava stem. Maleic, malic, adipic, tartaric, pyruvic, oxalic, and citric acids (1\%) were compared for the maximum yield by maintaining at $100{ }^{\circ} \mathrm{C}$ for $2 \mathrm{~h}$. In this study, oxalic and pyruvic acid showed 
the maximum yield, whereas malic and adipic acid showed the minimum yield. The maximum yield obtained by oxalic acid was $2.08 \mathrm{mg} / \mathrm{mL}$.

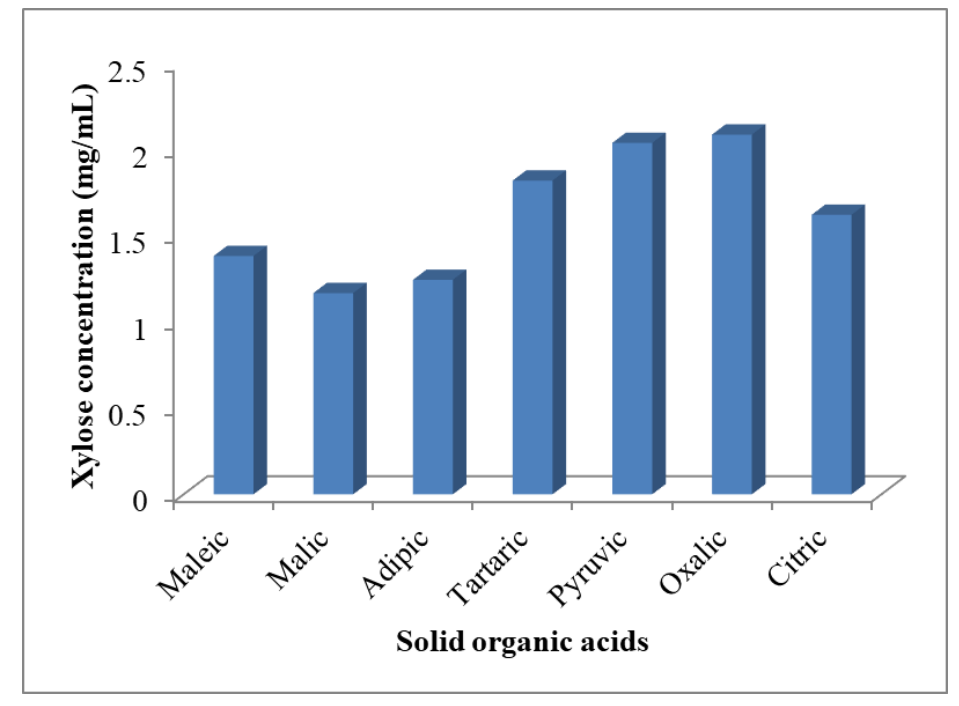

Figure 2 Effect of solid organic acids on xylose concentration for coarse particles of cassava stem.

Figure 3 shows the effect of liquid organic and inorganic acids on xylose concentration for coarse particles of cassava stem (>250 $\mu \mathrm{m})$. Hydrochloric, sulfuric, phosphoric, nitric, formic, acetic, and perchloric acids (1\%) were used for pretreatment by maintaining at $100^{\circ} \mathrm{C}$ for $2 \mathrm{~h}$. Hydrochloric acid and formic acid showed the maximum yield, whereas acetic and nitric acid showed the minimum yield. The maximum yield obtained by hydrochloric acid was $1.34 \mathrm{mg} / \mathrm{mL}$. By comparing both the solid organic and liquid organic and inorganic acids, hydrochloric acid showed the maximum yield. This also revealed that the yield was maximum for coarse particles. Between solid and liquid acids, oxalic acid produced the maximum xylose concentration of $2.08 \mathrm{mg} / \mathrm{mL}$. Hence, oxalic acid was further used for acid pretreatment.

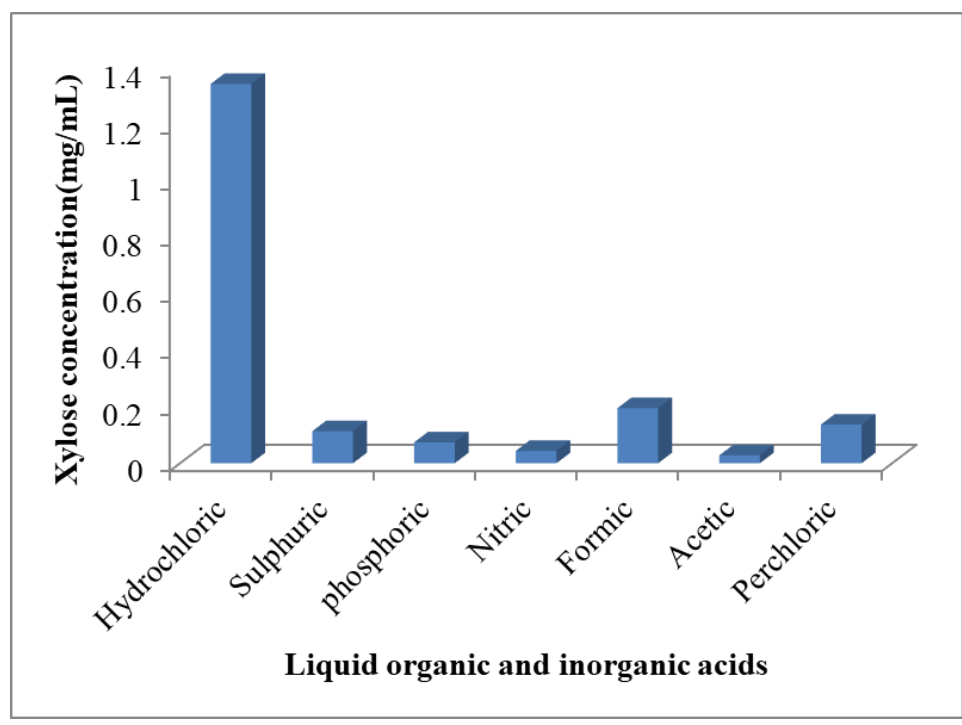

Figure 3 Effect of liquid organic and inorganic acids on xylose concentration for coarse particles of cassava stem. 
Figure 4 represents the effect of oxalic acid concentration on xylose concentration for coarse particles of cassava stem. The oxalic acid concentration varied between 0.5 and $3 \%(\mathrm{w} / \mathrm{v})$ and was maintained at $100^{\circ} \mathrm{C}$ for $2 \mathrm{~h}$. The maximum yield was obtained using $1 \%$ oxalic acid.

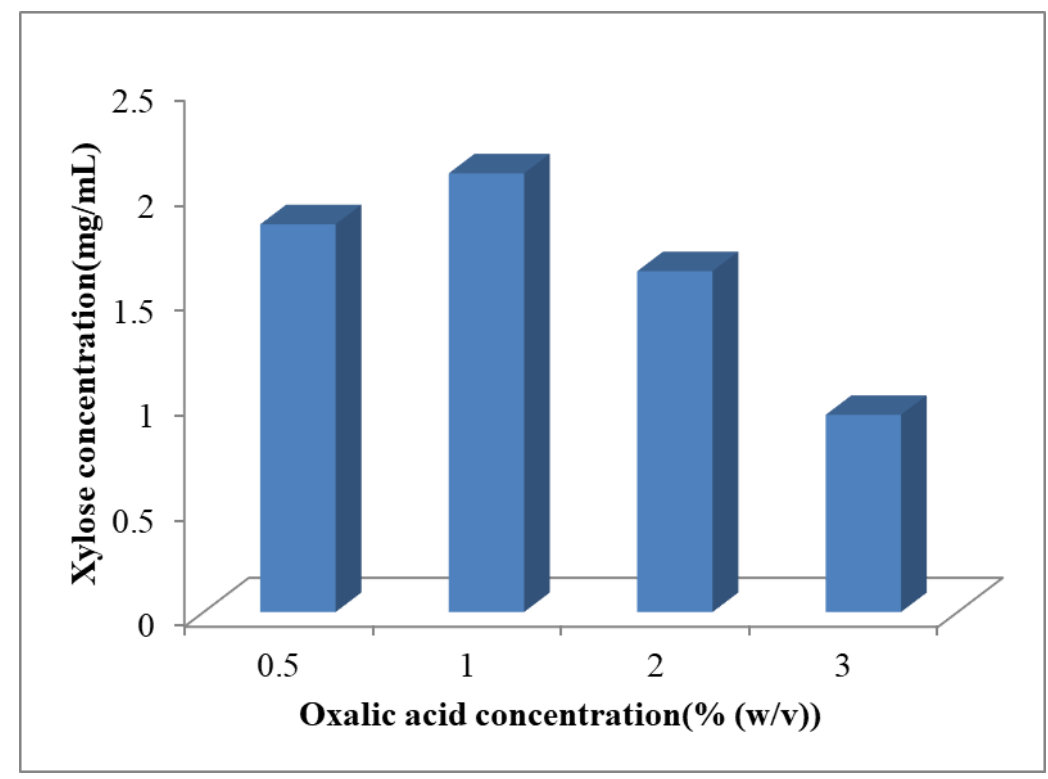

Figure 4 Effect of oxalic acid concentration on xylose concentration for coarse particles of cassava stem.

Figure 5 reveals the effect of solid loading on xylose concentration for coarse particles of cassava stem. The solid loading varied as $5,10,15$, and $20 \mathrm{~mL}$ of oxalic acid and was maintained at $100{ }^{\circ} \mathrm{C}$ for $2 \mathrm{~h}$. The maximum yield was obtained from $10 \mathrm{~mL}$ of oxalic acid solution per gram of cassava stem.

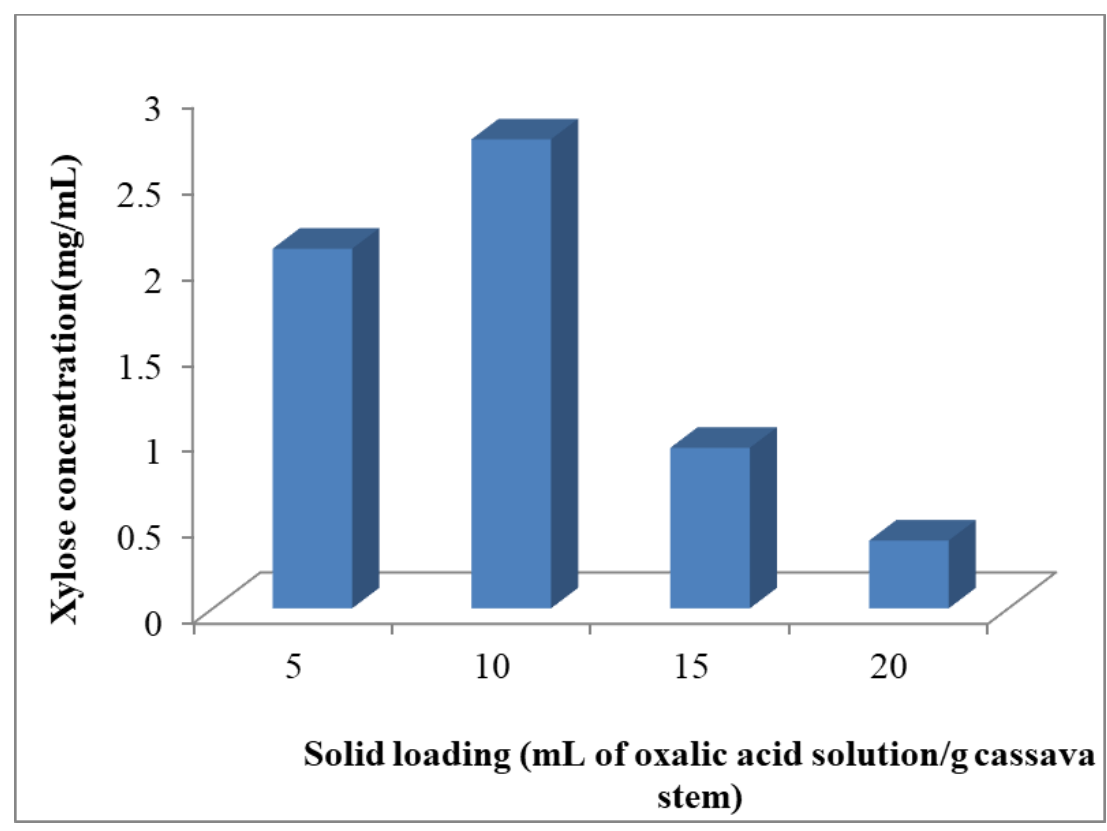

Figure 5 Effect of solid loading on xylose concentration for coarse particles of cassava stem. 
Figure 6 represents the effect of reaction time on xylose concentration for coarse particles of cassava stem. The reaction time varied as $20,30,60,120,180,240$, and $300 \mathrm{~min}$. The reaction was maintained at $100{ }^{\circ} \mathrm{C}$ using $10 \mathrm{~mL}$ of $1 \%(\mathrm{w} / \mathrm{v})$ oxalic acid solution per gram cassava stem. The yield was found to be maximum at $120 \mathrm{~min}$.

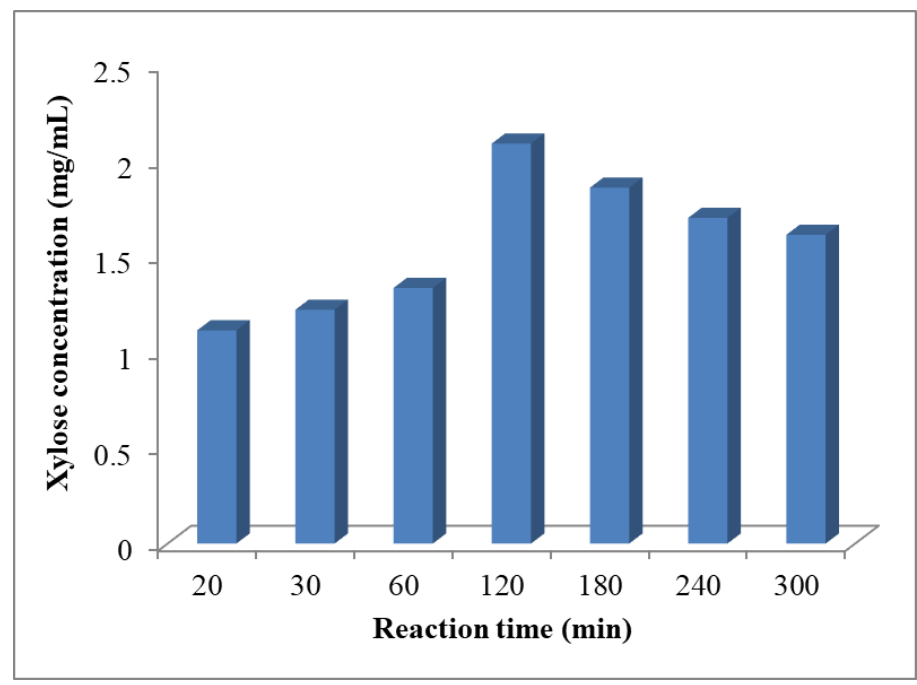

Figure 6 Effect of reaction time on xylose concentration for coarse particles of cassava stem.

Figure 7 represents the effect of alkali on percentage delignification for coarse particles of cassava stem at $100{ }^{\circ} \mathrm{C}$ for $1 \mathrm{~h}$. Next, 1\% sodium hydroxide, sodium hydroxide, and potassium hydroxide mixture, sodium hydroxide, and urea mixture, potassium hydroxide and urea mixture, and potassium hydroxide were maintained at $100{ }^{\circ} \mathrm{C}$ for $1 \mathrm{~h}$. A combination of sodium hydroxide and potassium hydroxide and sodium hydroxide and urea mixture showed the maximum delignification, whereas a mixture of potassium hydroxide and urea and potassium hydroxide showed the minimum delignification. The maximum delignification was obtained by a combination of sodium hydroxide and urea (27.03\%).

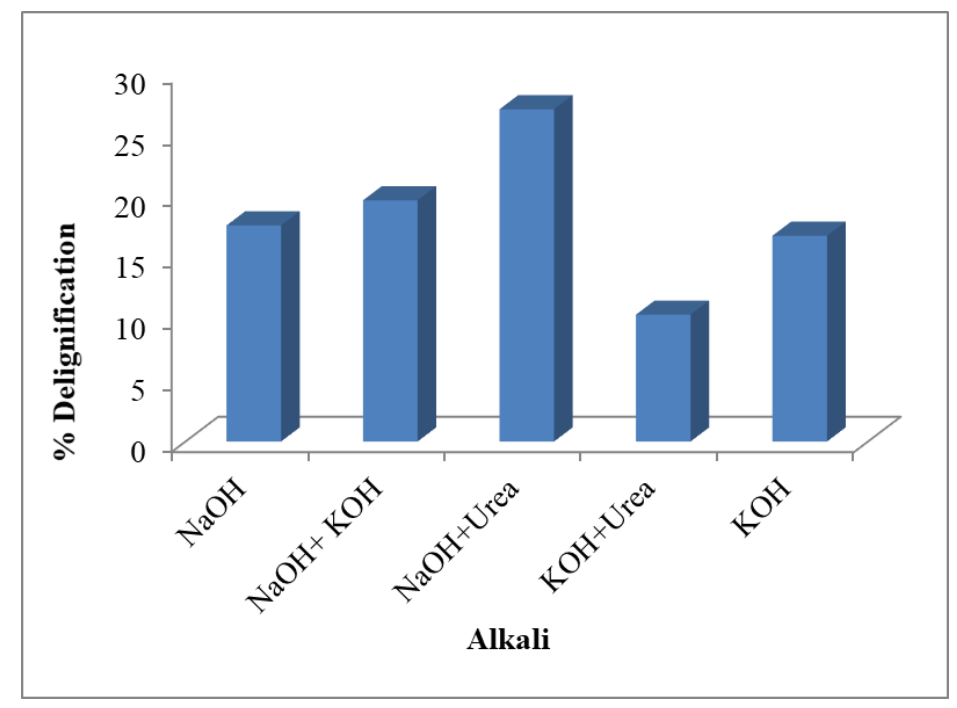

Figure 7 Effect of alkali on percentage delignification for coarse particles of cassava stem at room temperature of $100{ }^{\circ} \mathrm{C}$ for $1 \mathrm{~h}$. 
Figure 8 represents the effect of $\mathrm{NaOH}$ and urea mixture on the percentage delignification for coarse particles of cassava stem at $100{ }^{\circ} \mathrm{C}$ for $1 \mathrm{~h}$. The concentration of sodium hydroxide and urea mixture varied as 5,10 , and $15 \%$. The maximum delignification was obtained with $10 \%$ sodium hydroxide and urea mixture.

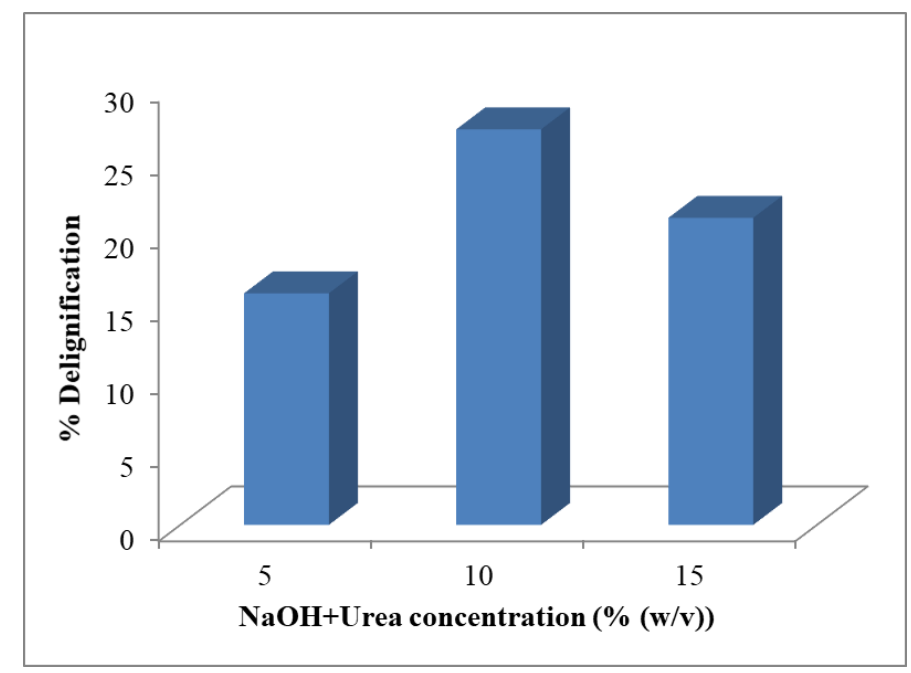

Figure $8 \mathrm{Effect}$ of $\mathrm{NaOH}$ and urea mixture on percentage delignification for coarse particles of cassava stem at $100^{\circ} \mathrm{C}$ for $1 \mathrm{~h}$.

Figure 9 reveals the effect of reaction time on the percentage delignification for coarse particles of cassava stem at $100^{\circ} \mathrm{C}$. The reaction time varied as $30,60,120$, and $180 \mathrm{~min}$. The maximum yield was obtained at $60 \mathrm{~min}$.

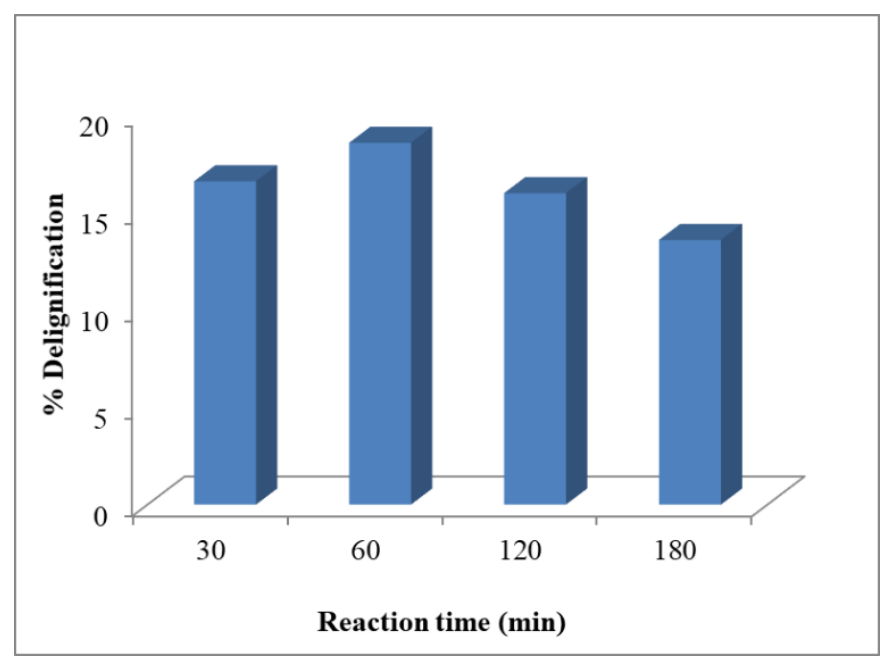

Figure 9 Effect of reaction time on percentage delignification for coarse particles of cassava stem at $100^{\circ} \mathrm{C}$ for $1 \mathrm{~h}$.

Figure 10 shows the effect of solid ( $\mathrm{NaOH}$ and urea mixture) loading on the percentage delignification for coarse particles of cassava stem at $100^{\circ} \mathrm{C}$ for $1 \mathrm{~h}$. The solid loading varied as 5,10 , and $20 \mathrm{~mL}$ of alkali solution per gram of cassava stem and was maintained at $100{ }^{\circ} \mathrm{C}$ for $1 \mathrm{~h}$. The maximum delignification was obtained with $5 \mathrm{~mL}$ of sodium hydroxide and urea solution per gram 
of cassava stem. After pretreatment, a cellulose recovery of $98.55 \%$ was achieved using the acidalkali pretreatment method.

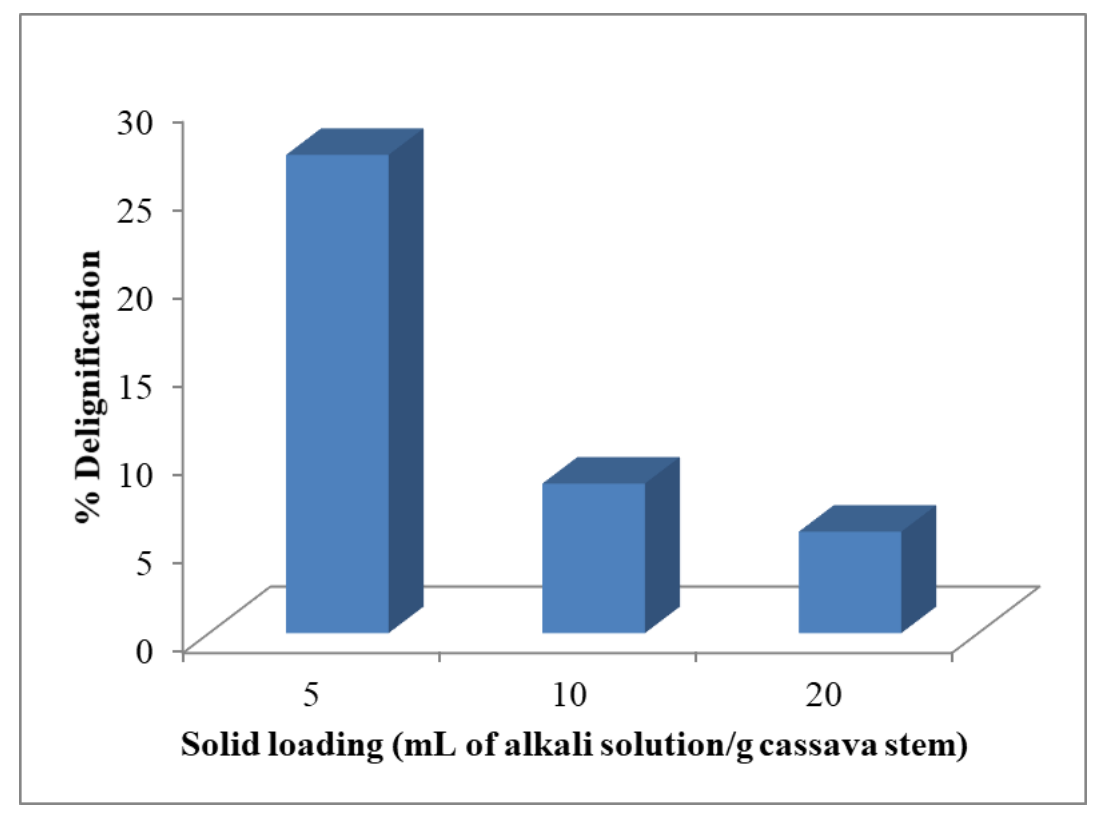

Figure 10 Effect of solid ( $\mathrm{NaOH}$ and urea mixture) loading on the percentage delignification for coarse particles of cassava stem at $100^{\circ} \mathrm{C}$ for $1 \mathrm{~h}$.

\section{Conclusions}

The current study assessed the applicability of a hybrid pretreatment method-acid treatment followed by alkali for the production of fermented sugars from cassava stem. The substrate was initially treated with acid ( $1 \%$ oxalic acid at $100^{\circ} \mathrm{C}$ for $2 \mathrm{~h}$ ), followed by treatment with $10 \% \mathrm{NaOH}-$ urea mixture (by mixing $5 \mathrm{~g}$ each of $\mathrm{NaOH}$ and urea in $100 \mathrm{~mL}$ of water) at $100{ }^{\circ} \mathrm{C}$ for $1 \mathrm{~h}$. After pretreatment, a cellulose recovery of $98.55 \%$ was achieved using the acid-alkali pretreatment.

\section{Acknowledgments}

We would acknowledge our heartfelt thanks to the Management of University of Technology and Applied Sciences (Salalah College of Technology), Salalah, Sultanate of Oman, Kongu Engineering College, Perundurai, and Kumaraguru College of Technology, Coimbatore for the wonderful opportunity, continuing support and encouragement by providing necessary facilities for executing the research work.

\section{Author Contributions}

Selvaraju Sivamani: Conceptualization, Project administration, Supervision, Writing - Original draft, Writing - Review and editing; Rajoo Baskar: Conceptualization, Methodology, Supervision, Writing - Review and editing; Balasubramanian Lakshmi: Investigation, Writing - Original draft.

\section{Competing Interests}

We declare no conflict of interest with anyone 


\section{References}

1. Niphadkar S, Bagade $P, A$ Ahmed S. Bioethanol production: Insight into past, present and future perspectives. Biofuels. 2018; 9: 229-238.

2. Baral NR, Shah A. Techno-economic analysis of cellulose dissolving ionic liquid pretreatment of lignocellulosic biomass for fermentable sugars production. Biofuel Bioprod Biorefin. 2016; 10: 70-88.

3. Efroymson RA, Dale VH, Kline KL, McBride AC, Bielicki JM, Smith RL, et al. Environmental indicators of biofuel sustainability: What about context? Environ Manage. 2013; 51: 291-306.

4. Gómez-Baggethun E, de Groot R, Lomas PL, Montes C. The history of ecosystem services in economic theory and practice: From early notions to markets and payment schemes. Ecol Econ. 2010; 69: 1209-1218.

5. Dale BE. Feeding a sustainable chemical industry: Do we have the bioproducts cart before the feedstocks horse? Faraday Discuss. 2017; 202: 11-30.

6. Binder JB, Raines RT. Fermentable sugars by chemical hydrolysis of biomass. PNAS. 2010; 107: 4516-4521.

7. Mancini G, Papirio S, Lens PN, Esposito G. Solvent pretreatments of lignocellulosic materials to enhance biogas production: A review. Energy Fuels. 2016; 30: 1892-1903.

8. Chandrasekaran AP, Sivamani S. Statistical modeling and optimization of pretreatment for fermentable sugars production from cotton gin waste. Energ Source Part A. 2018; 40: 400-405.

9. Suresh T, Sivarajasekar N, Balasubramani K, Ahamad T, Alam M, Naushad M. Process intensification and comparison of bioethanol production from food industry waste (potatoes) by ultrasonic assisted acid hydrolysis and enzymatic hydrolysis: Statistical modelling and optimization. Biomass Bioenergy. 2020; 142: 105752.

10. Annamalai N, Al Battashi H, Anu SN, Al Azkawi A, Al Bahry S, Sivakumar N. Enhanced bioethanol production from waste paper through separate hydrolysis and fermentation. Waste Biomass Valorization. 2020; 11: 121-131.

11. Alexander RA, Innasimuthu GM, Rajaram SK, Jeganathan PM, Chellam Somasundarar S. Process optimization of microwave-assisted alkali pretreatment for enhanced delignification of Prosopis juliflora biomass. Environ Prog Sustain Energy. 2020; 39: 13289.

12. Kannah RY, Sivashanmugham P, Kavitha S, Banu JR. Valorization of food waste for bioethanol and biobutanol production. In: Food waste to valuable resources. Cambridge, Massachusetts: Academic Press; 2020.

13. Ralph J, Lapierre C, Boerjan W. Lignin structure and its engineering. Curr Opin Biotechnol. 2019; 56: 240-249.

14. Hyvärinen S, Damlin P, Gräsvik J, Murzin DY, Mikkola JP. Ionic liquid fractionation of woody biomass for fermentable monosaccharides. Cellulose Chem Technol. 2011; 45: 483-486.

15. Lenihan P, Orozco A, O'neill E, Ahmad MN, Rooney DW, Walker GM. Dilute acid hydrolysis of lignocellulosic biomass. Chem Eng J. 2010; 156: 395-403.

16. Ragauskas AJ, Huang F. Chemical pretreatment techniques for biofuels and biorefineries from softwood. In: Pretreatment techniques for biofuels and biorefineries. Berlin, Heidelberg: Springer; 2013.

17. Olanbiwoninu AA, Odunfa SA. Enhancing the production of reducing sugars from cassava peels by pretreatment methods. Int J Sci Technol. 2012; 2: 650-657. 
18. Singh DP, Trivedi RK. Acid and alkaline pretreatment of lignocellulosic biomass to produce ethanol as biofuel. Int J Chemtech Res. 2013; 5: 727-734.

19. Magesh A, Preetha B, Viruthagiri T. Statistical optimization of process variables for direct fermentation of 226 white rose tapioca stem to ethanol by Fusarium oxysporum. Int J Chem Tech Res. 2011; 3: 837-845.

20. Sivamani S, Baskar R, Chandrasekaran AP. Response surface optimization of acid pretreatment of cassava stem for bioethanol production. Environ Prog Sustain Energy. 2020; 39: e13335.

21. Magesh A, Preetha B, Viruthagiri T. Direct fermentation of 226 white rose tapioca stem to ethanol by Fusarium oxysporum. JIRCAS Working Rep. 2012: 394-397. Available from: https://www.cabdirect.org/cabdirect/abstract/20123395828.

22. Chandrasekaran AP, Sivamani S, Ranjithkumar V. Characterization of combined organicinorganic acid-pretreated cassava stem. Int J Environ Sci Technol. 2017; 14: 1291-1296.

23. Updegraff DM. Semimicro determination of cellulose in biological materials. Anal Biochem. 1969; 32: 420-424.

24. Sluiter A, Hames B, Ruiz R, Scarlata C, Sluiter J, Templeton D, et al. Determination of structural carbohydrates and lignin in biomass. Laboratory analytical procedure. Golden, Colorado: National Renewable Energy Laboratory; 2010; TP-510-42618.

25. Sadasivam S, Manickam A. Biochemical method for agricultural science. New Delhi: Willey, Eastern Ltd; 1992.

26. Thiex N, Novotny L, Crawford A. Determination of ash in animal feed: AOAC official method 942.05 revisited. J AOAC Int. 2012; 95: 1392-1397.

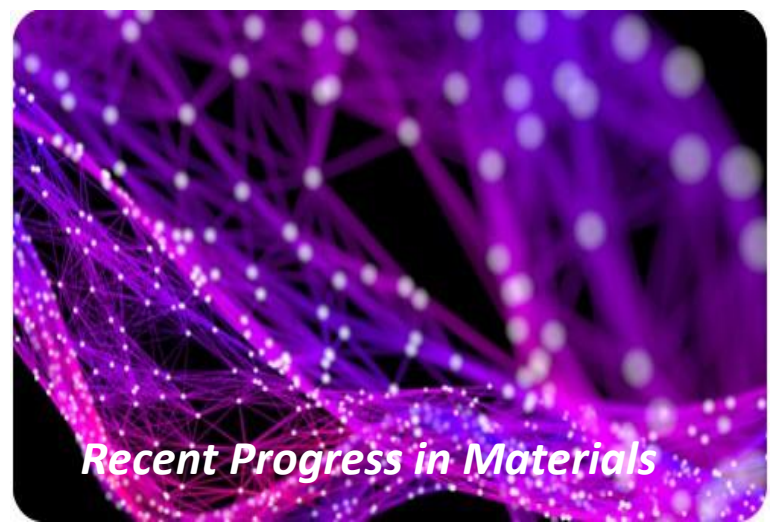

Enjoy Recent Progress in Materials by:

1. Submitting a manuscript

2. Joining in volunteer reviewer bank

3. Joining Editorial Board

4. Guest editing a special issue

For more details, please visit: http://www.lidsen.com/journals/rpm 